\title{
Fostering professionalism in doctor of nursing practice students
}

\author{
Sarah M. Fitz, Kathleen J.H. Sparbel, Kelly D. Rosenberger, Susan J. Corbridge \\ College of Nursing, University of Illinois at Chicago, United States
}

Received: December 4, 2019

Accepted: January 10, 2020

Online Published: February 24, 2020

DOI: $10.5430 /$ jnep.v10n5p56

URL: https://doi.org/10.5430/jnep.v10n5p56

\begin{abstract}
The Doctor of Nursing Practice (DNP) is the terminal degree for advanced practice nurses. All documents outlining competencies for doctorally-prepared nurses include professionalism as a requirement. While fostering professionalism in DNP students is expected of faculty, there is little data or guidance that describes specific educational strategies related to this concept. The available literature related to professionalism in healthcare education is not specific to advanced practice nursing. The purpose of this article is to define domains of professionalism for DNP-prepared advanced practice nurses, discuss specific examples of each domain, and propose strategies for including the domain within the DNP curriculum.
\end{abstract}

Key Words: Professionalism, Doctor of nursing practice, Advanced practice nurses, Nursing education

\section{INTRODUCTION}

Professionalism is an inherent attribute to advanced practice nursing. However, definitions of professionalism in nursing vary and developing students' professional behavior is noted to be a complex, evolving, dynamic and multidimensional process. ${ }^{[1]}$ Traditionally, graduate nursing education and practice have incorporated an informal process of role modeling to teach professional values and behaviors. Given the complexity of modern advanced practice nursing with the shift to online educational activities and the variety of students entering nurse practitioner programs from diverse social, cultural, educational and societal backgrounds, role modeling alone is no longer sufficient for students to develop professional competencies. To date, there is little published research regarding professionalism of nurse practitioners. Additionally, there is little guidance in the literature of an overarching conceptual definition of professionalism as a competence or how to best teach and evaluate profession- alism for advanced practice nursing students. While some literature addresses development of professionalism among medical, dentistry, and pharmacy students, ${ }^{[2-6]}$ it is limited and there is a dearth of comparable literature specific to advanced practice nursing students. Utilizing the core values of the National League for Nursing and the American Association of Colleges of Nursing (AACN) approved Common Advanced Practice Registered Nurse (APRN) DoctoralLevel Competencies, ${ }^{[7]}$ this article defines professionalism and identifies key attributes of professionalism in nursing. It links professionalism attributes to The Essentials of Doctoral Education for Advanced Nursing Practice ${ }^{[8]}$ for Doctor of Nursing Practice (DNP) Essentials II, III, V, VI, and VIII and provides exemplar teaching strategies to empower nursing faculty to foster professionalism in their students, with reference to the National Organization of Nurse Practitioner Faculties (NONPF) nurse practitioner core competencies. ${ }^{[9]}$

The National League for Nursing's (NLN) core values of car-

*Correspondence: Sarah M. Fitz; Email: safitz@uic.edu; Address: Department of Biobehavioral Health Sciences, College of Nursing, University of Illinois at Chicago, United States. 
ing, integrity, diversity and excellence provide a framework to define professionalism in nursing. ${ }^{[10]}$ Professionalism encompasses demonstration of four key principles: 1) the display of caring; 2) the commitment to integrity; 3) the respect of diversity; and 4) the pursuit of excellence. Caring denotes showing empathy, compassion, and respect for the values and opinions of others. Nurses demonstrate integrity by taking accountability and responsibility for their own behaviors, communications, and activities. The respect for diversity is displayed through an attitude of inclusiveness and advocacy for the interests of others, while the pursuit of excellence is exhibited through the nurse's dedication and commitment to the continuous improvement of the quality of services provided and of the nursing profession. Table 1 provides examples of nursing professionalism behaviors under the framework of the NLN core values.

Table 1. Components of Professionalism, Adapted from NLN values ${ }^{[10]}$

\begin{tabular}{|c|c|c|c|}
\hline Caring & Integrity & Diversity & Excellence \\
\hline $\begin{array}{l}\text { Be forgiving. Everyone make } \\
\text { mistakes \& should be given a fair } \\
\text { chance. }\end{array}$ & $\begin{array}{l}\text { Be ethical. Maintain } \\
\text { standards \& do what is right. } \\
\text { Be honest \& forthright. Do }\end{array}$ & $\begin{array}{l}\text { Be civil. Treat people with } \\
\text { respect even if you do not } \\
\text { agree with them. }\end{array}$ & $\begin{array}{l}\text { Strive to be the best. } \\
\text { Be prepared \& current. Keep } \\
\text { knowledge \& skills up to } \\
\text { date. }\end{array}$ \\
\hline $\begin{array}{l}\text { Be a communicator. Invite ideas \& } \\
\text { feedback. }\end{array}$ & not rumor or gossip. & $\begin{array}{l}\text { Be consistent } \& \text { accepting of } \\
\text { other values/beliefs. }\end{array}$ & Be involved in your \\
\hline Be empathetic \& compassionate. & $\begin{array}{l}\text { Be accountable \& } \\
\text { responsible. Do what you say } \\
\& \text { follow up. }\end{array}$ & $\begin{array}{l}\text { Be collaborative \& partner } \\
\text { with other professions to }\end{array}$ & $\begin{array}{l}\text { profession at the local, state } \\
\& \text { national levels. }\end{array}$ \\
\hline \multirow[t]{2}{*}{ Be emotionally intelligent. } & & benefit patients. & Be punctual \& on time. \\
\hline & $\begin{array}{l}\text { Be a role model. Your words } \\
\& \text { actions reflect on your } \\
\text { profession. }\end{array}$ & Be an advocate for others. & $\begin{array}{l}\text { Be appropriate in } \\
\text { appearance. }\end{array}$ \\
\hline
\end{tabular}

Professionalism is at the core of APRN daily encounters with patients, faculty, colleagues and the community. Professionalism is also essential to maintaining the public trust. Indeed, Gallop Poll rankings consistently report nurses highest for honesty and ethical standards. ${ }^{[11]}$ As registered nurses, APRN students should exhibit the core NLN nursing professional competencies. The doctorally prepared advanced practice nurse is expected to exemplify the pinnacle of clinical nursing leadership and practice. Therefore, in addition to the core professionalism attributes, nurse educators are challenged to intentionally elevate professionalism competencies taught to APRN students to meet the doctoral advanced practice role and responsibility.

In 2006, AACN released The Essentials of Doctoral Education for Advanced Nursing Practice (DNP Essentials). The DNP Essentials "define the curricular elements that must be present in DNP programs". ${ }^{[8]}$ The eight domains of the Essentials guide curriculum development, evaluation, and accreditation of DNP education. While the NLN core values of professionalism are intrinsic to the DNP role, the Essentials do not explicitly detail professional standards and competencies relative to advanced practice. This can make it challenging for faculty to develop curricula that ensure the scope of professional attributes and student competencies are systematically incorporated in teaching-learning strategies. Those competencies, however, are inferred and threaded within multiple Essentials domains.
While nationally accepted competency documents are established for each of the four advanced practice roles in nursing and the AACN DNP Essentials establishes educational standards for doctorally prepared nurses, a common framework of definitions and competencies across APRN roles was lacking. In response to recommendations to identify competencies common across the four APRN roles, AACN convened the APRN Competency-Based Education for DoctoralPrepared APRNs Work Group in 2016. That Workgroup, comprised of representatives of 25 organizations involved in APRN education, licensure, certification and accreditation, proposed the Common Advanced Practice Registered Nurse Doctoral-Level Competencies in October 2017. ${ }^{[7]}$ The APRN Work Group identified "Professionalism" as Domain 5; described as "Demonstrates a commitment to carrying out professional responsibilities and an adherence to ethical principles"(p. 7). ${ }^{[7]}$ Selected verbiage in the Domain 5 competencies relate to the NLN core nursing professionalism competencies of caring (compassion), integrity, and diversity. Excellence is closely reflected in Domain 1 (Patient Care), Domain 2 (Knowledge of Practice), Domain 3 (Practice-Based Learning and Improvement), and Domain 8 (Personal and Professional Development). Competency progression indicators within each domain are identified at two points of time in the student's education; when the student first enters a meaningful clinical experience, and when the student completes the doctoral program. 
DNP nursing faculty are tasked with mentoring doctoral nursing students to build on professionalism competencies taught during prelicensure education, and further developed through clinical nursing practice. Currently, the DNP Essentials is the foundational document guiding APRN nursing curriculum and accreditation. The professionalism competencies noted by NLN and AACN can be addressed through incorporating appropriate teaching-learning strategies within the DNP Essentials framework. Relevant professionalism content and suggested teaching-learning strategies will be illustrated for five of the DNP Essentials Domains: 1) Essential II. Organizational and systems leadership; 2) Essential III. Clinical scholarship and analytical methods; 3) Essen- tial V. Health Care Policy; 4) Essential VI. Interprofessional Collaboration; and 5) Essential VIII. Advanced Nursing Practice ${ }^{[8]}$ Selected teaching-learning strategies and relationship to national competencies are found in Table 2. This article examines how guiding documents for APRN education in the United States provide parameters for development of professionalism for DNP students. Educational requirements for APRNs are different geographically, and many APRNs are masters prepared. While the requirements of these degree programs differ, and the breadth of educational experiences may vary depending on the degree program, the tenets of professionalism discussed may be applied to any advanced practice nursing students.

Table 2. Strategies for professionalism development related to competencies and NLN values

\begin{tabular}{|c|c|c|c|}
\hline $\begin{array}{l}\text { DNP Essential } \\
\text { Competency }\end{array}$ & $\begin{array}{l}\text { AACN Common } \\
\text { Competency }\end{array}$ & $\begin{array}{l}\text { National Nursing } \\
\text { League Value }\end{array}$ & Exemplar Teaching-Learning Strategies \\
\hline \multirow{4}{*}{$\begin{array}{l}\text { II: Organizational and } \\
\text { Systems Leadership } \\
\text { for Quality } \\
\text { Improvement and } \\
\text { Systems Thinking }\end{array}$} & \multirow{4}{*}{$\begin{array}{l}\text { Domain 7: } \\
\text { Systems-Based } \\
\text { Practice }\end{array}$} & \multirow{4}{*}{$\begin{array}{l}\text { Caring } \\
\text { Integrity } \\
\text { Excellence }\end{array}$} & Team based learning modules with alternating group roles \\
\hline & & & Involvement in student organizations \\
\hline & & & Involvement in professional organizations \\
\hline & & & System-focused DNP project \\
\hline \multirow{6}{*}{$\begin{array}{l}\text { III: Clinical } \\
\text { Scholarship and } \\
\text { Analytical Methods for } \\
\text { Evidence-Based } \\
\text { Practice }\end{array}$} & \multirow{6}{*}{$\begin{array}{l}\text { Domain 2: } \\
\text { Knowledge of } \\
\text { Practice }\end{array}$} & \multirow{6}{*}{$\begin{array}{l}\text { Excellence } \\
\text { Integrity }\end{array}$} & $\begin{array}{l}\text { Highlight faculty scholarship (grants, publications, practice, professional } \\
\text { organizational leadership) }\end{array}$ \\
\hline & & & $\begin{array}{l}\text { Build assignments/grading rubrics throughout DNP curricula which require } \\
\text { evidence-based literature review (including levels of evidence) to support } \\
\text { interventions. }\end{array}$ \\
\hline & & & Translation of DNP project into publishable manuscript \\
\hline & & & $\begin{array}{l}\text { Mentor students to disseminate scholarly work through conference } \\
\text { presentations }\end{array}$ \\
\hline & & & Mentorship of students within professional organizations \\
\hline & & & Mentorship of students within local and state APRN organizations \\
\hline \multirow{4}{*}{$\begin{array}{l}\text { V: Health Care Policy } \\
\text { for Advocacy in Health } \\
\text { Care }\end{array}$} & \multirow{4}{*}{$\begin{array}{l}\text { Domain 5: } \\
\text { Professionalism } \\
\text { Domain 6: } \\
\text { Systems-Based } \\
\text { Practice }\end{array}$} & \multirow{4}{*}{$\begin{array}{l}\text { Diversity } \\
\text { Caring } \\
\text { Excellence }\end{array}$} & $\begin{array}{l}\text { Involve students with local, state, national legislators related to health policy } \\
\text { issues }\end{array}$ \\
\hline & & & $\begin{array}{l}\text { Service project collaborating with community stakeholders based on needs } \\
\text { assessment }\end{array}$ \\
\hline & & & $\begin{array}{l}\text { Use of course work aimed at addressing core issues in advanced practice } \\
\text { nursing }\end{array}$ \\
\hline & & & Group policy-writing project as part of professional course work \\
\hline \multirow{4}{*}{$\begin{array}{l}\text { VI: Interprofessional } \\
\text { Collaboration for } \\
\text { Improving Patient and } \\
\text { Population Health } \\
\text { Outcomes }\end{array}$} & \multirow{4}{*}{$\begin{array}{l}\text { Domain 7: } \\
\text { Interprofessional } \\
\text { Collaboration }\end{array}$} & \multirow{4}{*}{$\begin{array}{l}\text { Diversity } \\
\text { Integrity }\end{array}$} & Interprofessional simulation \\
\hline & & & $\begin{array}{l}\text { Standardized patient encounter } \\
\text { Clinical rotations foster interaction and collaboration with students/clinicians } \\
\text { from other professions }\end{array}$ \\
\hline & & & Expert guest lecturers from specialty areas \\
\hline & & & Interprofessional Immersion Day events, workshops, journal clubs \\
\hline \multirow{5}{*}{$\begin{array}{l}\text { VIII: Advanced } \\
\text { Nursing Practice }\end{array}$} & \multirow{5}{*}{$\begin{array}{l}\text { Domain 1: Patient } \\
\text { Care }\end{array}$} & \multirow{5}{*}{$\begin{array}{l}\text { Diversity } \\
\text { Caring } \\
\text { Integrity } \\
\text { Excellence }\end{array}$} & $\begin{array}{l}\text { Clinical rotations providing care for diverse group of patients in clinical } \\
\text { specialty area }\end{array}$ \\
\hline & & & Discussion/reflection ethical guidelines for clinical practice \\
\hline & & & Implementing evidence-based practice change (e.g. DNP project) \\
\hline & & & Foster values of continuous professional development \\
\hline & & & $\begin{array}{l}\text { Didactic and clinical examples of seeking and applying current clinical } \\
\text { practice guidelines }\end{array}$ \\
\hline
\end{tabular}


2. DNP ESSENTIAL II: ORganizational AND SYSTEMS LEADERSHIP

DNP-prepared advanced practice nurses function as leaders in their specialty fields. The National Organization of Nurse Practitioner Faculties (NONPF) competencies include seven leadership components ${ }^{[9]}$ which align with the DNP Essential II: "Organizational and Systems Leadership for Quality Improvement and Systems Thinking". ${ }^{[8]}$ Although the NONPF competencies and DNP Essentials include leadership as distinct educational competencies, leadership is a professional attribute which is interwoven throughout many other core competencies of DNP-level advanced nursing practice.

Nursing education fosters development of leadership skills from prelicensure through the terminal degree. Nursing programs encourage the NLN value of excellence by providing both academic and clinical leadership experiences. Postlicensure, practicing nurses also need mentored leadership development; this essential guidance results in an enhanced level of professionalism and role modeling behaviors. Continued growth is essential to nurses assuming greater leadership roles and individual effectiveness. ${ }^{[12]}$ Faculty can provide APRN students with developmental leadership opportunities through institutional graduate student nursing organizations and mentor students to become involved in state and national professional organizations while still in school.

DNP-prepared nurses serve as patient advocates by creating organizational change and building policies to improve the lives of patients and populations. These nurses improve healthcare practices by leading evidence-based practice change. Introducing these changes requires knowledge of how to investigate, collaborate, and amend processes to improve patient care. Prior to the DNP degree becoming the terminal degree for advanced practice nurses, many of these skills were gained through on-the-job training in collaboration with other healthcare professionals. While DNP graduates continue to collaborate with colleagues to build on their experience with leadership roles, new DNP graduates are prepared through the DNP curriculum to lead practice change. Team-based learning is used in many DNP courses as a tool to foster leadership; students are required to lead the team during their coursework, and students are given the opportunity to provide open, constructive feedback to each other. The DNP project serves as the cornerstone of leadership curriculum for educating students in interpersonal skills related to leadership. Additionally, this project gives the DNP graduate firsthand experience with working within the healthcare system to lead and sustain practice change for improving patient care. Faculty can further enhance development of leadership roles by mentoring students to develop practice standards and healthcare outcomes in diverse patient populations, and collaborate with community stakeholders to create workforce development and other programs that improve access to healthcare in diverse underserved and/or rural communities.

\section{DNP ESSENTIAL III: ClINICAL SCHOL- ARSHIP AND ANALYTICAL METHODS}

DNP Essential III: "Clinical Scholarship and Analytical Methods for Evidence-Based Practice" calls on the DNPeducated nurse to step into the role of a leader in translating knowledge to clinical practice. This component of DNP education sets forth expectations that nurses critically analyze data from clinical practice and determine if this data reflects excellence in evidence-based practice. The DNP graduate synthesizes available literature with current practices and database information, and uses it to determine if practice change is necessary. Moreover, the DNP nurse leads evidence-based practice change to elevate clinical practice to the highest possible standard. This also includes dissemination of clinical practice findings at specialty or regional conferences.

Clinical scholarship can be both demonstrated by faculty and produced through student assignments. The prime exemplar of clinical scholarship for DNP students is through the development, implementation, and evaluation of the DNP project. Students learn to critically analyze and synthesize research, practice, and policy evidence related to a practice or system problem. They also learn how to analyze outcomes and create a scholarly report of clinical projects related to quality improvement. Other scholarship activities can also be implemented during the DNP program to build a foundation of scholarship throughout the curriculum. Faculty exemplify their own scholarly work to students through practice grants, published articles, or other scholarly achievements announced within platforms visible to students (e-mail or television screens in common areas are methods of displaying this information). Students can be prompted to investigate and provide evidence for interventions on case study assignments during the core and specialty course work for any of the APRN programs. Additionally, students should be encouraged throughout their nursing education to seek scholarship and practice grant opportunities. Institutions can support development of clinical scholars through workshops on how to develop scholarly posters and presentations, and by sponsoring financial support for professional conferences where students' works are disseminated. They can also stimulate interest in creative clinical scholarship by illustrating examples of translation of scholarly work into clinical practice, such as patents, license copyrights, or mobile application (APP) 
development.

NONPF also recommends that faculty have specific measurable components for assessing the quality of scholarly products (NONPF, 2016). These measurements should be based on national credentialing standards and may vary depending on the DNP specialty program and institution. ${ }^{[13]}$ Additionally, using transparency in the assessment process helps students to understand the expectations and align their work with the curriculum requirements. Such evaluations should occur frequently during the DNP program in order to continuously assess each student's performance and redirect their learning focus as needed.

\section{DNP Essential V: Health CARE POL- ICY}

DNP graduates use their nursing knowledge and leadership skills to advocate for patients through the creation of healthcare policies. APRNs embody the NLN value of caring for diverse populations by leading policy change that addresses healthcare disparities and improves access to quality healthcare for all populations. DNP Essential V: "Healthcare Policy for Advocacy in Health Care" specifically discusses the ways in which DNP graduates advocate for social justice issues and patient access as well as the importance of advocacy for the profession of nursing and the nurse's role in policy creation. ${ }^{[8]}$ The Common APRN Competencies addresses DNP graduates' involvement in healthcare policy within both the Professionalism domain and the Systems-Based Practice domain. ${ }^{[7]}$ DNP faculty can provide students with examples of healthcare policy and advocacy through their own policy work and by involving students in policy creation. Course work provides students the opportunity to work as part of a team addressing a current healthcare delivery issue. The students research and evaluate potential solutions to the problem, and then work to determine and recommend a policy change to address the issue. Students can gain valuable experience in policy advocacy through interacting with local, state, and federal legislators on healthcare or APRN professional issues. The faculty provide feedback about the students' policy plans using their own experiences, and help the students understand areas where they may realistically face barriers when advocating for policy changes.

DNP graduates also find opportunities for policy work within local, state, regional, and national professional organizations. Again, nurse educators and experienced APRNs can provide valuable mentorship to new DNP graduates by encouraging involvement in these professional organizations. Advocating for these organizations to provide discounted member fees for students and new graduates also promotes student and new graduate involvement.

\section{DNP ESSENTIAL VI: INTERPROFES- SIONAL COLLABORATION}

Evidence supports improving patient care and provider satisfaction through interprofessional teamwork in clinical practice. ${ }^{[14]}$ The NONPF Core Competencies include interprofessional leadership and collaboration ${ }^{[9]}$ which align with DNP Essential VI: "Interprofessional Collaboration for Improving Patient and Population Health Outcomes". ${ }^{[8]}$ Core competencies for interprofessional education (IPE) and collaborative practice have been established. ${ }^{[15]}$ Under the overarching domain of Interprofessional Collaboration (IPC), the four topics of values and ethics, roles and responsibilities, interprofessional communication, and teams and teamwork intertwine to develop the clinician's competencies in providing collaborative care across health care disciplines. Starting at the prelicensure level, nurse educators are seeking opportunities to provide IPE experiences for students, and student feedback has been positive. ${ }^{[16]}$ Students report that opportunities for learning in collaboration with different disciplines allows new practitioners to gain the perspectives of other clinicians. ${ }^{[17]}$

To meet the core competencies of providing IPC, consistent messaging within the curriculum as well as opportunities to practice developing interprofessional behaviors is required. Values and ethics clarification, and understanding roles and responsibilities that support IPC may involve didactic coursework within each discipline curriculum, but are enhanced through interdisciplinary activities, such as IPE Immersion Day group discussions, cross-disciplinary courses, journal clubs, and workshops. Clinical practicum settings provide an ideal venue to break down barriers between professions and develop communication and teamwork skills. Model exemplars of interprofessional clinical practicum experiences include longitudinal rural health community service projects involving APRN, physician, and pharmacist student teams, multidisciplinary student team rounding in acute care settings, and preceptor-mentored interprofessional student teams in primary or subspecialty care. Interprofessional collaboration can also be practiced through development and implementation of the DNP project, changing healthcare through an IPC initiative.

The NLN value of caring can be demonstrated through advanced practice nurses' communication abilities. Communication is one of the observable methods of exhibiting professional behavior. DNP faculty model professional communication in their interactions with students and other colleagues. During their clinical rotations, students learn how their pre- 
ceptors communicate with patients, families, healthcare staff, and medical colleagues. Additionally, role-playing activities in which students practice verbal presentations of patient cases or calling another healthcare professional provides tools for students to practice their communication skills.

Simulation and standardized patient encounters are also useful tools for students to practice their professional communication skills. Students can practice calling another provider for a consult, talking to bereaved families, providing care through tele-health experiences, and therapeutic communication with patients. Faculty and standardized patient actors can provide immediate constructive feedback about students' communication skills. Simulation also provides a safe, observable opportunity for students from various healthcare disciplines to practice their patient care skills and professional interactions. Foundational to building these competencies, faculty must be transparent within the syllabus about the course objectives and expectations of professional behavior and communication. Faculty can provide exemplar videos for student learning, such as those created by NONPF in the faculty-preceptor portal (https : //www. nonpf . org/pa ge/PreceptorPortal_Main). ${ }^{[18]}$ Course assignments and grading rubrics should provide faculty with objective assessment methods and provide guidance to mentor students to attain competence.

\section{DNP ESSEntial VIII: AdVanced nURs- ING PRACTICE}

DNP Essential VIII identifies the vital foundational practice competencies for all DNP specialty practices. "All DNP graduates are expected to demonstrate refined assessment skills and base practice on the application of biophysical, psychosocial, behavioral, sociopolitical, cultural, economic, and nursing science as appropriate in their specialty focus area". ${ }^{[8]}$

Professional development includes self-development beyond the basic advanced practice graduate level to improve competencies in specialty practice. Competence in advanced practice is the method in which clinical knowledge of the profession is applied. Practice is conducted with the application of nursing knowledge for the assessment and care of diverse patient populations to improve outcomes, the measurement of quality indicators, the development and enhancement of practice protocols, the evaluation of systems of care, and the analysis of healthcare delivery models. ${ }^{[7]}$ While professionalism in advanced nursing practice broadly encompasses leadership, clinical scholarship, and policy advocacy, the focus of this domain is on behaviors and professional competencies that relate directly to the APRN's clinical practice.

Published by Sciedu Press
Nursing faculty need specific, measurable criteria for assessing students' abilities to take ownership of their responsibilities as providers. While certain professional behaviors may seem inherent to nursing, faculty must take intentional measures to ensure these behaviors are discussed in didactic curricula, displayed in interactions in academic settings, and objectively measured as part of the passing requirements in clinical courses. These behaviors include arriving on time and prepared to work, turning in assignments on time, responding to clinical and academic e-mail correspondence in a timely and professional manner, dressing in a manner appropriate to the professional setting, taking personal ownership for patient care priorities, and communicating in a respectful manner with everyone in the clinical setting. Examples of including these behaviors in nursing curricula include role-playing activities to practice patient presentations on rounds or formal case study presentations in front of fellow students. Additionally, rubrics for clinical courses should include specific criteria for timely arrival to the clinical site, appropriate dress, and responsiveness to the needs of the patient population.

Mentoring students to take professional responsibility and ownership for one's own practice goes beyond expectations for timeliness, appearance, and communication. Becoming invested as an APRN denotes continual learning in the profession. Initially, APRNs demonstrate taking profession responsibility for one's own practice through attaining the DNP and professional specialty certification, but attaining practitioner expertise can also be enhanced through additional professional credentials or certificates, and recognized through national organizations, such as becoming a Fellow of the American Association of Nurse Practitioners (FAANP). The APRN is expected to maintain an intellectual curiosity, and pursue continuing education that will support growth in clinical competencies. Faculty can foster this value by emphasizing that APRN education is a step in professional development; with the terminal clinical degree being part of the trajectory of lifelong learning.

Taking responsibility for professional practice extends to developing APRN student mentoring skills. It can be uncomfortable for students to analyze peers or mentor others in developing competencies. Faculty can provide opportunities for students to practice constructive peer review in classroom assignments, with the goal of improving individual performance and the quality of a group project. This can build confidence in the student's ability to improve quality in a clinical practice as an APRN. It can also instill value in mentoring other professionals, including future students, as taking personal responsibility for one's clinical practice. 


\section{Conclusion}

Competencies outlined by NONPF and AACN detail the ways in which DNP programs elevate the National League of Nursing values to a doctoral level. Publications from various other healthcare specialties detail how educational programs can incorporate these professional values into their didactic and clinical courses. This includes incorporation of professional behaviors into syllabi, modeling of professional communication by faculty, faculty mentorship of students to instill professional values, and hands on clinical and simulation examples of the professional competencies. There remains a paucity of literature specific to DNP education of advanced practice registered nurses outlining detailed guid- ance for programs to incorporate professionalism into the curricula and clinical experiences for diverse student cohorts. DNP graduates learn to apply evidence in the clinical practice setting to achieve the highest level of healthcare delivery; in this same manner, DNP educational programs must utilize evidence-based educational methods to deliver content specific to professionalism. This requires educators to undertake evaluation of programmatic strategies for providing meaningful professionalism content. DNP programs can collaborate and share their strategies to drive continuous development for professionalism in DNP education.

\section{Conflicts of Interest Disclosure}

The author declares that there is no conflict of interest.

\section{REFERENCES}

[1] Ghadirian F, Salsali M, Cheraghi MA. Nursing professionalism: an evolutionary concept analysis. Iran J Nurs Midwifery Res. 2014 Jan-Feb; 19(1): 1-10.

[2] Christie C, Bowen D, Paarmann C. Effectiveness of faculty training to enhance clinical evaluation of student competence in ethical reasoning and professionalism. Journal of Dental Education. 2007; 71(8): 1048-1057.

[3] Goldie J, Dowie A, Cotton P, et al. Teaching professionalism in the early years of a medical curriculum: A qualitative study. Medical Education. 2007; 41(6): 610-617. PMid:17518842 https: //doi.org/10.1111/j.1365-2923.2007.02772.x

[4] Jha V, Bekker HL, Duffy SRG, et al. Perceptions of professionalism in medicine: A qualitative study. Medical Education. 2006; 40(10): 1027-1036. PMid:16987195 https://doi.org/10.111 $1 / j .1365-2929.2006 .02567 . x$

[5] Shtaynberg J, Rivkin A, Shah B, et al. A quantitative professionalism policy in a community pharmacy introductory pharmacy practice experience. American Journal of Pharmaceutical Education. 2013. 77(10): 217. PMid:24371341 https://doi.org/10.5688/ajpe 7710217

[6] Ziring D, Danoff D, Grosseman S, et. al. How do medical schools identify and remediate professionalism lapses in medical students? A study of U.S., and Canadian medical schools. Academic Medicine 2015. 90(7): 913-920. PMid:25922920 https://doi.org/10.1 097/ACM. 0000000000000737

[7] American Association of Colleges of Nursing. Common advanced practice registered nurse doctoral-level competencies. 2017 [cited 2019 Sept 11]. Available from: https ://www . aacnnursing . org/Portals/42/Academi cNursing/pdf/Common-APRN-Doctoral-Competencies.pdf

[8] American Association of Colleges of Nursing [Internet]. The essentials of doctoral education for advanced nursing practice. 2006 Oct. [cited 2019 Jul 16]. Available from: https : //www . aacnnursing. org/Portals/42/Publications/DNPEssentials.pdf

[9] National Organization of Nurse Practitioner Faculties. (2017). Nurse Practitioner Core Competencies Content. Available from: https://cdn.ymaws.com/www.nonpf .org/resource/resmg $r /$ competencies/2017_NPCoreComps_with_Curric.pdf
[10] National League for Nursing: Mission and values [Internet] National League for Nursing; c 2016 [cited 2019 Sep 23]. Available from: http://www.nln.org/accreditation-services/the-n ln-commission-for-nursing-education-accreditation - (cnea)

[11] Honest/Ethics in Professions [Internet]. Gallup Poll; c2019 [cited 2019 Sep 23]. Available from: https ://news.gallup.com/poll /1654/honesty-ethics-professions.aspx

[12] Abraham PJ. Developing nurse leaders: A program enhancing staff nurse leadership skills and professionalism. Nurse Administration Quarterly. 2011; 35(4): 306-312. PMid:21900815 https : //doi.org/10.1097/NAQ.0b013e31822ecc6e

[13] National Organization of Nurse Practitioner Faculties. White Paper: The Doctor of Nursing Practice Nurse Practitioner Clinical Scholar [Internet]. National Organization of Nurse Practitioner Faculties; c 2016 [cited 2019 Sep 11] Available from: https://cdn. ymaws . com/www . nonpf .org/resource/r esmgr/docs/ClinicalScholarFINAL2016.pdf

[14] Smith CD, Balatbat C, Corbridge S, et al. Implementing optimal team-based care to reduce clinician burnout. NAM Perspectives [Internet]. c 2018. [cited 2019 May 1]. Available from: https://nam.edu/implementing-optimal-team-bas ed-care-to-reduce-clinician-burnout

[15] Interprofessional Education Collaborative. Core competencies for interprofessional collaborative practice: 2016 update. Interprofessional Education Collaborative; c 2016 [cited 2019 Sep 11]. Available from: https://nebula.wsimg.com/2f68a39520b03336b41038c37 0497473?AccessKeyId=DC06780E69ED19E2B3A5\&dispositi on=0\&alloworigin=1

[16] Gambino KM, Frawley S, Lu W. Working together.. Nursing Education Perspectives. Publish ahead of print 2019.

[17] Valenziano KB, Glod SA, Jia S, et al. An interprofessional curriculum to advance relational coordination and professionalism in early-career practitioners. MedEdPORTAL. 2018;14:10697. https : //doi.org/10.15766/mep_2374-8265.10697

[18] National Organization for Nurse Practitioner Faculties: Preceptor portal [Internet]. Washington, DC: National Organization for Nurse Practitioner Faculties [cited 2019 Nov 4]. Available from: https ://www.nonpf.org/page/preceptorportal_main 